\title{
JONATHAN EDWARDS AND HIS METHODOLOGY PROMOTING CONCERN FOR REVIVAL
}

\author{
DINU MOGA* \\ Emanuel University of Oradea
}

\begin{abstract}
In Edwards, we see the portrait of a man who knows how to merge in one vocation the ministry of a pastor and that of an evangelist. As a pastor, Edwards knew how to act soberly in supervising the flock of God. As an evangelist, he knew how to avoid any excess of emotionalism and how to focus his efforts on maintaining steadiness and stability in his care for the human souls. He saw himself under the obligation to take the message of God to all those who struggled in this life. In his mind it was clear that God chooses his servants and then commissions them to preach the gospel with passion.
\end{abstract}

KEYWORDS: pastor, revivalist, preaching, evangelist, Scripture

\section{Introduction}

This work deals with a more practical part of Edwards' theology. The focus of our interest will be first on Edwards as a revivalist preacher, second on his attitude towards revival and then on the methods he used in order to bring about revivals in New England.

This paper is an attempt to deal with Edwards's qualities as a pastor and revivalist. Once again, we see in Edwards the portrait of a well-balanced evangelist, concerned to instruct the mind as well as touch the heart. Here we place the emphasis on the importance of preaching the whole truth. Edwards preached about God's judgement as well as his mercy and love. Edwards's preaching was always very clear and aimed to produce understanding. It will be argued later by the proponents of the 'new measures' evangelism that any doctrinal statements are unnecessary in revival. In this chapter we wish to explain that, from a biblical point of view, the theologically informed sermon can touch the heart of the sinner.

* DINU MOGA (MTh in Historical Theology, Westminster Theological Seminary, 2005; PhD in Theology, Babeș-Bolyai University, 2015) teaches Systematic and Historical Theology at Emanuel University of Oradea. Email: mogadinu@gmail.com. 
The affections are always stirred by an appeal to the intellect. Edwards preaches intelligently in order to be able to preach emotionally. Affection, says Edwards, represents a response made by the whole person to a reality. Regarding the practical means advocated by Edwards we discover that the basic ones are two: prayer and fasting. Both illustrate Edwards's view of the concurrence between God's sovereignty and man's responsibility.

\section{Jonathan Edwards: Pastor and Revivalist}

There are two ways in which people have looked at Jonathan Edwards. In our day, he has become widely known and viewed as a specialist in revivalism and a passionate supporter of conversion. But for many people Edwards personifies the pastor who is also skilful in doing the work of an evangelist. The quality of his pastoral abilities is evident in his tendency to exhibit distinctly pastoral preferences and his ability to verify whether church members had implemented the message in their conduct based on their own testimony and reports by their neighbour (Eversley 1999: 113116).

Although he was a pastor, as well as a passionate writer and scholar, Edwards was also a skilful evangelist in New England. The combination of these two callings is very rare today, although one would like to see it more often in our churches. As a pastor, Edwards understood that ministers must be positively inclined to the work of revival (Edwards Works 4: 375). He knew in his heart that it was not enough simply to continue his work of preaching doctrine and labouring faithfully in his pastorate, while having an indifferent, or even a negative, outlook toward the revival.

Eversley notes that in the long tradition of American evangelism, very few revivalists have held a pastoral position. In saying that, he also charges revivalists with the tendency to be anti-intellectual. By contrast, asserts Eversley, 'Edwards, the intellectual, makes conversionism an appealing proposition for the academically inclined. He thought matters through' (Eversley 1999: 114).

From his position as pastor Edwards saw himself under the obligation to act soberly in supervising the flock of God. Excesses of emotionalism would not do for Edwards and his concern for this aspect of revivalism has helped shape his greater emphasis on maintaining steadiness and stability in his cure of souls.

As a pastor, Edwards believed that he had a divine calling and a great responsibility to take the message that God had given him to all those who struggled in this life. [See Edwards's published ordination sermons on John 13:15-16, 'Christ the Example of Ministers', in Edwards (Works 2: 960-965).] This was his motivation for evangelism. He was convinced that God chooses his servants and then commissions them to preach the gospel with passion. 
The goal of this was, as already shown, the advance of God's kingdom. Moved by the desire to see God's kingdom coming and seeing his role as a divinely commissioned minister in that kingdom, Edwards not only learned how to preach for the salvation of souls, but also succeeded in casting his shadow on American evangelicalism.

In the process of becoming one of the greatest evangelists of America Edwards was influenced in the art of preaching by his father and grandfather, Timothy Edwards and Solomon Stoddard. Bailey points to the fact that these two stood for Edwards as examples of powerful preachers in Connecticut Valley. [For some other important details regarding the sources of influences that contributed to the character of Jonathan Edwards as the preacher, see Bailey (2003: 68-76).] Kimnach, in his introduction to Sermon and Discourses 1720-1723, supports this observation when he writes:

Perhaps the two most important influences upon Edwards's preaching style were his father and his maternal grandfather, Timothy Edwards and Solomon Stoddard, the former as a living exemplar of the preacher during his son's formative years, the latter as a master preacher to the young journeyman who shared his Northampton pulpit from 1726 to 1729 . Edwards doubtless received his fundamental conception of the sermon form from his father, though Stoddard, a published critic of preaching, would certainly have suggested some master strokes to the preacher who was still developing his distinctive voice in the mid1720s (Kimnach in Edwards Works 10: 10-11).

Stoddard, more than Timothy Edwards, taught his young associate to preach with the aim of seeing souls converted. Under the influence of Locke's theory of ideas, Edwards was convinced of the power of words and the ideas they represented and, consequently, he crafted his sermons so that his ideas might appeal to his hearers' feelings and thus move their affections towards God. Miller illustrates the same truth when he asserts that Edwards's ,pulpit oratory was a consuming effort to make sounds become objects, to control and discipline his utterance so that words would immediately be registered on the senses not as noises but as ideas' (Miller 1953: 158).

Thus, we have before us a man who combined two of the most important qualifications the church of God needs: the ministry of a pastor, concern for the spiritual well-being of his flock, and the ministry of an evangelist, concerned with the salvation of souls from the fire of hell.

\section{Edwards's Attitude towards Revival}

In discussing Edwards's attitude towards revival, we need to underline again something on which Edwards is very clear, and which has already been mentioned. Firstly, Edwards considered the work of revival as being 'the work of God, not the work of man'. Edwards shows that: 'Its beginning 
has not been of man's power or device, and its being carried on depends not on our strength or wisdom' (Edwards Works 4: 384). Man must acknowledge that and to submit his endeavours and works to the will of God, seeing himself as dependent on God's power and will.

Nevertheless, Edwards also believed in man's responsibility to sustain and promote the work of revival. He was convinced that all Christians have a duty to seek to bring about the work of revival within the scope of their calling and abilities. In this way, we arrive at Edwards's second clarification. Having established the truth regarding the sovereign work of God in revival, he is quick to support the minister's role in promoting revival:

but yet God expects of all, that they should use their utmost endeavours to promote it, and that the hearts of all should be greatly engaged in this affair (Edwards Works 4: 384).

He puts this principle in the most forthright terms:

At such a time as this, when God is setting his King on his holy hill of Zion, or establishing his dominion, or showing forth his regal glory from thence, he expects that his visible people, without exception, should openly appear to acknowledge him in such a work, and bow before him, and join with him (Edwards Works 4: $370)$.

Edwards makes specific application of this idea to various classes, to civil rulers and to ministers (Edwards Works 4: 370-374). It must be underlined that nowhere does Edwards indicate that ministers, or anyone else, are to seek to initiate a work of revival, or bring one into being. But once such work has begun, it is for God's people, and particularly for ministers, to work to promote revival. This is what Edwards says:

But above all other... ministers... should arise and acknowledge and honour him in such a work as this and do their utmost to encourage and promote it. For to promote such a work is the very business which they are called and devoted to; 'tis the office to which they are appointed, as co-workers with Christ (Edwards Works 4: 374).

Edwards stresses that ministers, in particular, must ensure that they personally are participants in the work of revival. A lack of interest in this work has, for Edwards, serious consequences upon the church and upon the minister himself. Such an attitude puts the church in the situation of losing its confidence in the work of revival and the minister can no longer expect to enjoy its glorious benefits. Edwards comments: 'And if we really hinder and stand in the way of the work of God, whose business above all others it is to 
promote it, how can we expect to partake of the glorious benefits of it?' (Edwards Works 4: 376).

Once again, we see in Edwards the portrait of a theologically well-balanced evangelist. In times of revival he attributes to God the power to perform the work but sees himself directly responsible to do his duty to promote that work. To do otherwise would mean for him losing the Godgiven opportunity and the benefits that accompany it.

\section{The Content of Edwards's Preaching for Revival}

He Preached Solidly the Word of God

The most important way in which Edwards influenced and sustained the revival was through the ministry of preaching the gospel. His preaching for revival is likely to differ in many respects from the way in which contemporary evangelists conduct their evangelistic campaigns today. With respect to the manner and content of preaching, Edwards has a great deal to say about how ministers should preach in time of revival. There are two emphases noticeable in his attitude towards preaching.

As a pastor and evangelist, the first need stressed by him was the acquisition of a clear understanding of the Word of God. [For a more detailed account about the way Edwards studied the Bible and was influenced by it in his life and ministry see Turnbull (1958: 68-78); see also Marsden (2003: 8) where he makes the comment, quoting at the end of it Karl Pfisterer, that 'to live with Edwards day by day is to encounter someone who refracted virtually everything through 'the prism of Scripture'.] He recognised this need because he believed that the revealed Word of God contains the key to the understanding of the mysteries of life and death. For that reason, he saturated almost every sermon, from text to doctrine to application, with Scripture (Bailey 2003: 67). He associated every argument with Scripture, almost without fail. From his writings, it becomes noticeable that his life as a pastor and revivalist revolved continually around the Word of God. Even a cursory reading of his sermons demonstrates the zeal he had for the written Word. He was certain of the power which the Scriptures possessed to instruct and to guide human reason in divine things. Bailey notes in this respect that as Edwards ministered to his listeners through the proclamation of the gospel, he enthusiastically employed the Scriptures as the 'aid to reason' (Bailey 2003: 64-68). Thus, he anchored his sermons in what he considered to be the objective, special revelation of God and the power which alone can change man's life.

Gerstner explains that during his pastoral ministry Edwards preached every doctrine that he found in the Bible. His texts ranged over the entire Bible, through every book. Among his topics, we find included some of the most difficult ones to explain, including a number less likely to be consid- 
ered for evangelism today. But Edwards was nonetheless eager to preach about God's sovereignty and man's responsibility; he delighted to preach about grace and about law; he was concerned to preach about individual piety and about social obligations, and he desired to preach about principles and about persons. [Turnbull explains that Edwards found his theological ideas and the doctrine to preach from his biblical knowledge and an intensive study of the Bible. His prominent doctrines were the sovereignty of God, the depravity of man and the gospel of grace. Edwards was always writing about them and making them the heart of his preaching (Turnbull 1958: 83-91).]

Essentially, he preached the whole truth, as he saw it, and his preaching was always very clear, aiming to produce understanding.

The steps taken to produce this understanding included the preaching of sermons whose format was a three-part outline starting with the text and doctrine, leading mechanically to reasons or proofs and ending with uses. The important point that we make here is that as an evangelist Edwards relied heavily on Scripture, and in doing so he knew how to preach solidly and intellectually. With great effect, Gerstner has noticed that Edwards 'was an intellectual evangelist' and added to his observation the conclusion that, as an evangelist, Edwards 'preached solidly' (Gerstner 1991-1993: 1, volume $3)$.

In his essay (Smith 1999: 1-11), John Smith notes as well that the contribution made by Edwards's conception of the understanding and its role in religion is found in his insistence that the Spirit enlightens the mind to understand what is already contained in Scripture without any new revelation beyond what has already been revealed.

The way to draw men and women into Christ's kingdom, Edwards believed, was to 'set divine and eternal things in a right view' (Smith 1999: 56). The way the truths are put across must match the truths themselves.

We conclude, therefore, that the way Edwards preached was one which had the Word of God at its core. Scriptures were the text of his evangelistic sermons. The content of his messages came from God's revelation which he believed to be the only one capable of providing the light which illuminates the dark faculties of our present low state. Mastered by the power of the Word, his preaching was clear, and his aim was to produce understanding.

\section{He Preached to Touch Man's Feelings}

But Edwards was a preacher whose aim, besides that of producing understanding through his preaching, was also to stir affections in the heart. Edwards's second emphasis, therefore, in his preaching for revival was on reaching man's feelings. If earlier in his career, Edwards focused his attention more on a logical, theoretical style of argumentation, as he gained valuable pastoral experience, he recognized the importance of appealing to 
the emotions of his listeners. The question we could ask is how such rigidly structured sermons could have been expected to warm the heart and stir the affections? In his analysis of this matter, Simonson explain that such an aim is not difficult to achieve if the three-part sermon process is used: 'The rigid three-part form was not antithetical to his objective [warming the heart]. Plain doctrinal statements based on Biblical texts, followed by the intellectual reinforcement of the doctrine, thus prepared the congregation for the application which necessarily concerned the heart, will, and religious affections' (Simonson 1974: 111).

While his sermons, asserts Simonson, were neither 'a strict tour de force in logic nor some kind of artistic emotional appeal meant to lure people into agony or ecstasy devoid of intellectual content', he prepared his sermons diligently choosing his words meticulously so that they would have maximum impact on the understanding as well as on the heart and affections. Edwards himself says: 'All affections do certainly arise from some apprehension in the understanding' (Edwards Works 4: 386). Appealing to the intellect, Edwards's sermons conveyed to sinners the importance of religion, their own spiritual misery, the need for remedy, and the glory and sufficiency of the remedy. At the same time, they stirred the hearts of saints and quickened their affections. Always the overwhelming purpose was to convey the meaning of religious life. This required, first, a logical exposition of doctrine, to which listeners were to respond with intellectual conviction, and, second, an experiential and immediate sense of divinity to which they were to respond with willing consent (Simonson 1974: 112).

John Smith explains that Edwards used the idea of affections as a way of understanding the biblical 'fruits of the Spirit' in the experience of individual believers. This idea, he says, is of direct relevance in overcoming the unfortunate consequence of setting the 'heart' and the 'head' in opposition in matters of religion. An affection, explains Smith, such as love, joy and hope, is first of all an inclination of will, a response, not a reaction, made by the whole person to a reality-God, Scripture, neighbour-whose nature and 'excellency' have been properly understood by that person through the Bible, reason, and experience, or what Edwards called a 'spiritual understanding'. Smith continues to show that Edwards develops this thought in his usual serial form. There can be no love without knowledge, for it is contrary to the nature of the soul to love an entirely unknown object. Nor can the heart be fixed on an object of which there is no idea in the understanding (Smith 1999: 3).

Smith goes on to explain how Edwards develops the subject of affections, showing that our feelings are based on our understanding of the essential nature, often called by him the 'excellency' of what we are responding to in being thus affected. It was on this account that Edwards could insist that 
our love for God, for example, is authentic only if it has been induced or 'raised' by a spiritual understanding of the divine nature, beauty, and excellency.

Unfortunately, what has stood, and still stands, in the way of our grasping this point is the simple dichotomy-a legacy of the Enlightenmentwhich is supposed to exist between 'reason' and 'emotion'. The former is to stand for knowledge of things, while the latter is taken as an arbitrary expression of feeling totally disconnected from this knowledge. Edwards's theory of the affections was a victim of the same error at the time of the revivals; his critics mistook affections for emotions divorced from ideas, and thus failed to see the central importance of understanding in every affective response (Smith 1999: 5).

The important point to notice here is that for Edwards affections, either for good by right doctrine or for evil by wrong, had to be raised through understanding of the right doctrine. In Edwards's own words:

\begin{abstract}
All affections are raised either by light in the understanding, or by some errors and delusion in the understanding; for all affections do certainly arise from some apprehension in the understanding; and that apprehension must either be agreeable to truth, or else be some mistake or delusion; if it be an apprehension or notion that is agreeable to truth, then it is light in the understanding (Edwards Works 4: 386).
\end{abstract}

The other frequent mistake, reinforced by revivalist excesses, was the identification of affections with passions, even though Edwards made a point of distinguishing the two. The difference is clear: passions are such that the person is overwhelmed or obsessed by them and thus becomes a 'patient', whereas affections are active responses of the whole person, marked by selfcontrol. This means that the vital and urgent truth of the gospel must be communicated with a suitable earnestness and affection of manner. Again, in Edwards's own words:

I should think myself in the way of my duty, to raise the affections of my hearers as high as possibly I can, provided that they are affected with nothing but truth, and with affections that are not disagreeable to the nature of the subject... Our people don't so much need to have their heads stored, as to have their hearts touched; and they stand in the greatest need of that sort of preaching that has the greatest tendency to do this (Edwards Works 4: 387, 388).

Based upon this understanding of the faculties of the intellect and the heart, as well as the intimate relationship between the two, Edwards was convinced that 'if we ben't in good earnest in religion, and our wills and inclinations be not strongly exercised, we are nothing'. Crafting his sermons to appeal to the 'mind', meaning both the intellect and the heart, Edwards 
developed a religious psychology that took Puritan concern with religious feelings and fervour to a new level (Edwards Works 6: 192-195; Kimnach in Edwards (Works 10: 180-185, 198); (Edwards Works 2: 366-397).

\section{He Preached with Zeal and Fervency}

Preaching with zeal and fervency meant that Edwards preached passionately so as to lead souls through the difficulties of life toward eternal joy. A degree of pathos in preaching, with a manifestation of zeal and fervency, and with an earnest and even loud manner, is to be desired. Ministers are to aim to preach to bring people to Christ straight away-to press them to repent and turn to Christ.

No matter what else he intended, Edwards sought passionately and with great zeal to guide his sheep toward their destination. He directed those under his ministry to prepare for their future, eternal habitation. So, Edwards exhorted his listeners to live with an eye always toward heaven. Consequently, he fashioned his sermons in order to prepare souls for that heavenly state.

\section{Edwards's Motivations to Preach for Revival}

One of Edwards's specific motivations in preaching to bring people to the saving knowledge of God was his great interest and concern for the unsaved person. Harry Stout establishes that, as an evangelist, Edwards's primary concern in his regular sermons were the people lost in their sins. [Harry Stout quotes extensively from one of Edwards's unpublished sermon on Jonah 3:10, preached on 21st December 1727, Edwards Papers, Beinecke Library (Stout 1988: 146).] Even when Edwards was invited to preach ordination and installation sermons, he would expound the responsibilities of the pastor to propagate revivalism by bringing people to a saving knowledge of Christ.

Kimnach rightly observes that Edwards's mature vision of the ideal preacher is most completely delineated in the sermon preached at Robert Abercrombie's ordination. In the course of that sermon, Edwards invites the one who is being ordained to imitate the qualities which Jesus admired in John the Baptist, such as 'a burning and a shining light', and his fullness with the power of the Holy Spirit. The central point of his sermon underlines the fact that the minister has the responsibility to discover, to refresh and to direct the church, so that it becomes the means of bringing men out of darkness into God's marvellous light. Edwards considered ministers ineffectual if they manifested light without heat, for, he said, light alone 'will not be very likely to reach people's hearts, or to save their souls'. [See Edwards (Works 10: 25). The sermon is entitled 'The True Excellency of a Gospel Minister'; it was based on John 5:35 and was preached on August 30, 1744. 
Eversley also provides comments on this sermon in Eversley (1999: 121122).] It becomes evident that Edwards had no ambition but to serve God and his congregation with the gospel of God. He believed in preaching which magnified the majesty of God.

There was another fundamental principle which moved Edwards as a preacher. This was his abiding conviction that no gathered and visible people could stand in an ambiguous relationship to God: a person's or a group's lack of response to God's Spirit (and voice and providence) indicates his disposition against God. According to Edwards there is no neutral ground between God and the Devil who is the cause of man's neglect of God. Man is either concerned about his soul, and thus sees and hears God's calling voice, or he is turning his back on God thus provoking a great and dangerous neglect of his life. His aim was to persuade man through his preaching to a life submitted absolutely to the will of God. [In his sermon on Psalm 95:7-8, entitled 'The Duty of Hearkening to God's Voice', Edwards preached against those who postpone the affairs of their souls for all other affairs, and while they are doing this, they are losing their body and soul in hell, in spite of the fact that God calls upon them and entreats them to save themselves (Edwards Works 10: 438-450).]

Edwards directed his sermons to this end and did so with unrestrained passion. In his exposition on Psalm 95 he explains that God's will and mind are seen in all of creation. Likewise, God's voice calls out in all of history. Edwards declares in the exegesis of this Psalm that God communicates not only 'by his voice to us in Scripture' and 'his voice by his ministers and ambassadors' (Edwards Works 10: 441), but also through all His creation which proclaims God's goodness and mercy. Indeed, the sermon insists, it is divinity's design that the Holy Spirit's gracious internal voice or call comes to hearts softened and readied by means of the external call in the preaching of God's creative, verbal, and providential voice.

These convictions were enough to motivate Edwards to preach powerfully with the aim of bringing sinners to the knowledge of salvation.

\section{Practical Applications of Edwards's Doctrine of Revival}

Prayer and Fasting

Jonathan Edwards advocated a considerable number of practical means to promote revival. Among these, two of the most important, and most relevant for our discussion, are prayer and fasting. Prayer and fasting have to be, according to Edwards, the one great and principal means of carrying on the designs of Christ's kingdom in the world. As the most important on his list of preparatory means towards revival, prayer and fasting are to be used by all in their private capacity. In Some Thoughts, he argues this point in the following way: 
There is no way that Christians in a private capacity can do so much to promote the work of God, and advance the kingdom of Christ, as by prayer. By this even women, children and servants may have a public influence (Edwards Works 10: 518).

The reason Edwards must have attributed this primary position to these means of grace must find its echo in what Allan Story explains when he says that 'as a means of promoting revival, prayer illustrates well Edwards's view of the concurrence between God's sovereignty and man's responsibility, for it is both a great duty and also fully expressive of complete dependence' (Story 1994: 132). According to Scripture, prayer is a duty attributed to every believer and also a prerequisite for the activity of the Holy Spirit in revival. Edwards adduces numerous biblical passages to support his view. He makes his position clear when he says:

The Scriptures don't only direct and encourage us in general to pray for the Holy Spirit above all things else, but it is the expressly revealed will of God, that his church should be very much in prayer for that glorious outpouring of the Spirit that is to be in the latter days, and the things that shall be accomplished by it (Edwards Works 5: 348).

Where there is no prayer, there is a free and unhindered activity of the evil one. In his fast-day sermon from November 1740, which is short on doctrine and long on application, Edwards charges his congregation with not being sincere in their prayers for the outpouring of the Holy Spirit. He asserts that God is a prayer-hearing God who is willing to bestow blessings on those who ask for them in a sincere manner. In that sermon, Edwards launches into an impassioned plea for united prayer to secure the greater, more excellent blessings of the Spirit's presence. [The sermon is based on Luke 11:13, is entitled 'Praying for the Spirit' and is published in Edwards (Works 22: 213-223).] His conviction of the importance of united prayer as a means of furthering revival, evident here for the first time, grew stronger as he became involved with Scottish ministers in promoting transatlantic days of prayer and in publishing the Humble Attempt in 1747. [See Edwards (Works 5: 309-436; see also Edwards (Works 22:212).]

We notice from this sermon that whenever his parish seemed to be in decline, Edwards's main concern was to urge them to reaffirm their obedience and gratitude to God, to work more zealously to resist the Devil and to live up to their glorious reputation as people exceptionally enlightened and blessed by God. In the process of doing this Edwards understood that prayer and fasting were the means by which Satan could be defeated. He sees a great need for both in the land if a great outpouring of the Spirit of God is to be sought (Edwards Works 4: 517). 


\section{Material Support}

There are other important practical steps which Jonathan Edwards took in order to sustain and encourage revivalism. Earlier we noticed that the decadence in Edwards's land was especially evident among the young people and those who saw their life secured by the wealth of this world. It is evident that in his local community, Edwards knew how to use all the considerable means at his disposal-his office as a leader of Northampton society, and his position as pastor-to strengthen those converted and to continue to reinforce revivalism. Edwards shows a remarkable social awareness when he exhorts rich people to pursue, encourage and support the cause of the gospel financially. It is obvious that for Edwards the material aspects of revivalism are almost as important as the spiritual ones. Determined in his desire to see results from that point of view, Edwards suggests some of the ways in which wealth and power should be used for religious ends:

Great things might be done for the advancement of the kingdom of Christ at this day, by those that have ability, by establishing funds for the support and propagation of religion; by supporting some that are eminently qualified with gifts and grace, in preaching the Gospel in certain parts of the country that are more destitute of the means of grace; in searching out children of promising abilities... and bringing them up for the ministry; and in distributing books that are remarkably fitted to promote vital religion and have a great tendency to advance this work; .... and in establishing and supporting schools in poor towns and villages, which might be done on such a foundation as not only to bring up children in common learning, but also might very much tend to their conviction and conversion, and being trained up in vital piety (Edwards Works 4: 515).

He argues his point from Scripture using the example of David, 'that great king of Israel',... 'the highest in honour and dignity among God's people' but who advanced the 'honour and esteem of the congregation of Israel' and appeared 'foremost in the zeal and activity he manifested' for the Lord (Edwards Works 4: 513). Edwards's biblical argumentation makes also allusion to the 'primitive Christians' who were trained by the apostles to use their temporal goods in a manner which is not to be found among the rich people of his time. Edwards intends that the effect of these biblical examples would be to persuade the rich to share out a good part of what God had given them. The biblical argument continues with perhaps one of the most striking examples of contribution by the prosperous individuals from the biblical history of Israel. Edwards speaks here about the contribution of the heads of the tribes for the construction of the tabernacle mentioned in Exodus 35:21-29 (Edwards Works 4: 514). The sequence of biblical proofs is continued through the book of Nehemiah and other books of the Old Testament with the intent of building up the argument until it becomes a pow- 
erful eschatological argument meant to stir up the affluent Christian to offer their contribution towards the enlargement of the kingdom of God.

When the work of revival is received with a critical attitude, Edwards's plan of action is first to recommend reconciliation among persons involved, sometimes ministers, as a means of removing stumbling blocks to revivals (Edwards Works 4: 496) and secondly to promote the reaffirmation of orthodoxy (Edwards Works 4: 502). The key thought here is the need for the repentance of the believer and proper manifestations of his repentance are called for as a 'proper duty' (Edwards Works 4: 497). This is vitally important for Edwards because, for him, speaking against the work of revival means to speak against Christ and his work.

\section{Sermonic Utterances}

By the time revival came to Northampton and the Connecticut Valley, Edwards had served for several years as his grandfather's apprentice in Northampton. Therefore, he became familiar with the church's history during the six decades of Stoddard's leadership and that provided him with inside information in the construction of his revival sermons. [The previous revivals of his grandfather had clearly passed, leaving Edwards to conclude that, since his arrival in Northampton a year earlier, life in the land had become very much defiled. The decadence could be seen especially among the young people and those who saw their life secured by the wealth of this world. In one of his sermons, preached from Luke 1:17 in August 1741, Edwards's presumption was that the Lord had been in Northampton in the past, both in the revival of 1734-35 and earlier, in Stoddard's 'harvests', but now, before mid-1740, Edwards was sure that God had left. However, when his sermon was delivered in August 1741, we know, through his retrospective account in Some Thought, that Edwards was convinced that the Lord had returned. The sermon is entitled 'The Importance of Revival Among Heads of Families' and its aim is to show how revivals can become permanent and decline be permanently avoided. If the heads of the families, who are also heads of society, are reached, according to Edwards, we have reached the source of social and moral order (Edwards Works 22: 448-454; Edwards Works 4: 547-548, 293-347).]

Helped by this background, Edwards knew how to use various events in his preaching as instruments in making people aware of the need to turn to God. Many of his Northampton sermons are particularized redactions of local circumstances and events in Northampton (death, illness, politics, dissension, economic developments, drought, floods, earthquake, fires, accidents) in which, according to Edwards, 'The providence of God preaches'. [For a detailed analysis of various sermons and their evangelistic intent, see Westra (1999: 135-151).] These sermonic utterances offer complex expres- 
sions of Edwards's vision of the role of gospel ministry in action, practical applications of his doctrine of revival, his interpretations of God's providential voice, and the ways in which these shaped his pulpit messages and rhetoric.

An illustrative example of such a re-narrated event is the 'Great Earthquake' of November 1727. In his sermon, Edwards made use of that event to draw attention to the temporal state of New England. He explained that God used earthquakes to warn a covenant people of impending judgement. Edwards interpreted these local events as texts, which he skilfully wove together with biblical texts into a narrative of decline and revival under God's providence. Edwards always insisted upon the necessity of preaching to make his hearers fear the consequences of their sin. He argued that this is essential if the comforts of the gospel are to have any significance. Very significant to note here is the fact that Edwards used contrasts in a wellbalanced way. If he preached about hell, he also preached about heaven; if he preached about terror, he also preached about comfort. For example, the preaching of hell was right for Edwards as long as the comforts of the gospel were also preached. On the other side, the comforts of the gospel were not to be preached in such a way as to make the terrors of man's unbelieving condition appear any the less. Rather, they were to be preached to induce him to flee to Christ from his present condition.

This type of preaching, based on biblical truths, constituted a vital element in Edwards's revivalist efforts. This is what Edwards tells us about his method and experience in this area:

I am not afraid to tell sinners that are most sensible of their misery, that their case is indeed as miserable as they think it to be, and a thousand times more so; for this is the truth. Some may be ready to say that though it be the truth, yet the truth is not to be spoken at all times and seems not to be seasonable then: but it seems to me, such truth is never more seasonable than at such a time, when Christ is beginning to open the eyes of conscience. Ministers ought to act as coworkers with him; to take that opportunity, and to the utmost to improve that advantage, and strike while the iron is hot, and when the light has begun to shine, then to remove all obstacles, and use all proper means, that it may come in more fully, and the work be done thoroughly then. And experience abundantly shews, that to take this course is not of a hurtful tendency, but very much the contrary: I have seen, in very many instances, the happy effects of it, and oftentimes a very speedy happy issue, and never knew any ill consequence in case of real conviction, and when distress has been only from thence (Edwards Works 4: 392).

With respect to the same point Helen Westra makes the comment that Edwards's revivalist strategies tend to rhetorical intensification, extremity, and reiteration to fix these impressions 'deeper and deeper in the mind' and his 
sermonic discourse often deliberately follows 'the method God takes with the world—-to first reveal his dreadful justice and then reveal his grace, first by that which is terrible, then by that which is comfortable'. [See Edwards (Works 4: 397, 440). For a graphic description of Edwards's technique in presenting a sermon with the intent to revive and create conversion see Westra's comments on his sermon from Jeremiah 6:29-30 in Westra (1999: 140-143).]

In conclusion, we learn that Edwards is the type of evangelist who knows his people and their struggles. Being familiar with the history of his church constitutes for him a source of information that in turn helps him to construct his revival sermons. When people are characterised by decadence and religious decline Edwards knows how to make use of everyday events and happenings in his preaching to help people realize their need for repentance.

Edwards's conviction as a minister of revival is that a faithful minister must expose the truths in specific events that reveal God's relationship to a people. He is aware that a minister must communicate God's justice, warnings, and anger as well as his mercy, love and compassion as these are revealed in his Word. Unhesitatingly Edwards presents his sermonic renarrations of local events so that his interpretation of texts-historical, biblical, local, spiritual, and providential—all speak the same message from God, the same warning, the same plea for revival.

Thus, we notice that his evangelistic strategy is first to awaken people to their natural condition. When this step is accomplished his next step requires the kind of language that would convince sinners of God's justice in their condemnation, give them a willingness to be damned, and make them accept the hell they deserved. And the third phase was to prepare them to hear the gospel. The awful apprehensions of lakes of fire, blackness, bottomless pits, and divine wrath made way for the assurance that God offers them a Saviour. Edwards was convinced that the gift of all-sufficient grace would be meaningless unless men were first made sensible of their guilt and their deserved punishment. It was impossible, Edwards argued, that a person who is not first convinced of his guilt would be willing to accept the offer of the atonement. Edwards's logic not only made good theology; it was also sound rhetoric and psychology.

\section{Writings}

Edwards also promoted and encouraged the revival movement through his writings. He began a ten-year period of publication on the nature and effects of revivalism. [Contrary to this view is Lambert's contention that the revivalists used their series of narratives in order to invent the revival. 'It 
also inspired', he says, 'ministers and laypersons in communities throughout the colonies to stage and report similar revivals' (Lambert 1999: 9, 11).]

The first venture came out in 1737 in a A Faithful Narrative of the Surprising Work of God in the Conversion of Many Hundred Souls in Northampton (Edwards Works 4), a narrative that focused to an unfortunate degree on the unusual (and even unique) events of the 1734 Northampton revival, where he recounts the state of local degeneracy, the breakdown of family life and social contentiousness. In this study, Edwards provides detailed accounts of the religious experiences of a few notable converts. Elsewhere he tells us about the religious experiences of his disciples, David Brainerd, his wife, and other persons with whom he was intimately acquainted both before and after their conversions. [A more detailed analisys of these aspects can be found in Eversley (1999: 119-122). For a discussion regarding Brainerd's and Edwards's transitional status in the Protestant missionary movement, see Walls (2003: 248-265).]

Still early in his ministry, in a 1741 Yale Commencement Address which later became The Distinguishing Marks of a Work of the Spirit of God, Edwards referred with sympathy to the 'tears, trembling, groans, loud outcries, agonies of body, or the failing of bodily strength', which accompany revival. He argued that although Scripture did not specifically mention them all, God could not be confined to using for his glory only those signs which Scripture mentions (Edwards Works 4: 230-235).

Edwards's next written discussion of these things was published in 1742 as Some Thoughts on the Revival. Here we find a much more mature Edwards, one who had begun to see that distinctions had to be made among the various events that were all becoming lumped together as evidence of God's direct, supernatural work among his people.

Continued attacks on the Awakening, such as those of Charles Chauncey and distortions of the Awakening by 'friends' like James Davenport, led Edwards to produce his most important work, A Treatise concerning Religious Affections, in 1746. In one of his discussions, William K. B. Stoever explains that the Treatise concerning Religious Affections, produced in the controversial retrospect of the Great Awakening, was Edwards's 'fullest and most pointed statement about the nature and expression of true godliness'. [See Stoever (1996: 85). Stephen J. Nichols has labelled it 'a classic, a literary and a theological masterpiece', because it transcends generations and addresses numerous problems that overwhelm Christians and the church (Nichols 2001: 107).] Right from the start of Religious Affections, we see Edwards seeking to establish what the nature of true religion is (Edwards Works 2: 234). He offers us the privilege of understanding what constitutes a true converted believer. For Edwards, these are most important issues. They were not just the product of his imagination or of his desire for more inquiries into religion 
but were addressed during controversies and struggles with the opponents of revival. Edwards's purpose in Religious Affections, was to help individuals and churches distinguish true Christianity from the counterfeit.

Edwards also used his sermons in order to stimulate revival in his congregation. It is from his sermons that we learn how important it was for Edwards to emphasise the need for revival, not only during the mid-1730s and again for a time in the early 1740s but throughout his entire career.

Although death prevented Edwards from completing this proposed work, his collected sermons of almost thirty-five years may be viewed and valued together as a source of information on the theology of revival.

\section{Concluding Remarks}

In Edwards, we see the portrait of a man who knows how to merge in one vocation the ministry of a pastor and that of an evangelist. As a pastor, Edwards knew how to act soberly in supervising the flock of God. As an evangelist, he knew how to avoid any excess of emotionalism and how to focus his efforts on maintaining steadiness and stability in his care for the human souls. He saw himself under the obligation to take the message of God to all those who struggled in this life. In his mind, it was clear that God chooses his servants and then commissions them to preach the gospel with passion.

In the exercise of his preaching ministry for revival he was conscious that, on the one hand, revival is the work of God, not the work of man, and on the other hand, promoting the work of revival is the duty of every believer. Therefore, Edwards learned how to preach for the salvation of souls. He was aware that words carry with them power. Governed by this conviction Edwards saturated his messages with the Word of God. The aim of his preaching was to produce understanding and through the understanding to raise the hearers' affections and move them towards God.

\section{Bibliography}

Primary Sources

Edwards J (1972) Some Thoughts Concerning the Revival. In The Great Awakening. In Goen CG (ed) The Works of Jonathan Edwards, volume 4. New Haven, CT: Yale University Press.

Edwards J (1959) Religious Affections. In Smith JE (ed) The Works of Jonathan Edwards, volume 2. New Haven, CT: Yale University Press.

Edwards J (1972) The Distinguishing Marks. In The Great Awakening. In Goen CC (ed) The Works of Jonathan Edwards, volume 4. New Haven, CT: Yale University Press. 
Edwards J (1972) Unpublished Letter of May 30, 1735. In The Great Awakening. In Goen CC (ed) The Works of Jonathan Edwards, volume 4. New Haven, CT: Yale University Press.

Edwards J (1972) A Faithful Narrative of the Surprising Work of God in the Conversion of Many Hundred Souls in Northampton and the Neighbouring Towns and Villages In The Great Awakening. In Goen CC (ed) The Works of Jonathan Edwards, volume 4. New Haven, CT: Yale University Press.

Edwards J (1989) A History of the Work of Redemption. In Wilson JF (ed) The Works of Jonathan Edwards, volume 9 (New Haven, CT: Yale University Press.

Edwards J (1994) The Miscellanies, a-500. In Schafer TA (ed) The Works of Jonathan Edwards, volume 13. New Haven, CT: Yale University Press.

Edwards J (1999) Sermons and Discourses, 1730-173. In Valery MR (ed) The Works of Jonathan Edwards, volume 17. New Haven, CT: Yale University Press.

Edwards J (2000) The Miscellanies, Entry nos. 501-832. In Chamberlain A The Works of Jonathan Edwards, volumes 18. New Haven, CT: Yale University Press.

Edwards J (1957) Freedom of the Will. In Ramsey P (ed) The Works of Jonathan Edwards, volume 1. New Haven, CT: Yale University Press.

Edwards J (1970) Original Sin. In Holbrook CA (ed) The Works of Jonathan Edwards, volume 3. New Haven, CT: Yale University Press.

Edwards J (2001) Sermons and Discourses 1734-1738. In Lesser MX (ed) The Works of Jonathan Edwards, volume 19. New Haven, CT: Yale University Press.

Edwards J (1977) Apocalyptic Writings. In Stein SJ (ed) The Works of Jonathan Edwards, volume 5. New Haven and London: Yale University Press.

Edwards J (1980) Scientific and Philosophical Writings. In Anderson WE (ed) The Works of Jonathan Edwards, volume 6. New Haven, CT: Yale University Press.

Edwards J (2003) Sermons and Discourses, 1739-1742. In Stout HS and Hatch NO with Farley KP (eds) The Works of Jonathan Edwards, volume 22. New Haven and London: Yale University Press.

Grandison FC (1910) Lectures on Revivals of Religion, Harding WH (ed). New York and London.

Grandison FC (1878; reprint 1951) Lectures on Systematic Theology. Grand Rapids: Eerdmans.

\section{Secondary Sources}

Bailey RA (2003) Driven by Passion: Jonathan Edwards and the Art of Preaching. In Hart DG; Lucas SM, Nichols SJ (eds) The Legacy of 
Jonathan Edwards: America Religion and the Evangelical Tradition. Grand Rapids, MI: Baker Academics.

Chamberlain A (2000) Editor's Introduction. In The Miscellanies, Entry nos. 501-832. In The Works of Jonathan Edwards, volume 18. New Haven, CT: Yale University Press.

Eversley WVL (1999) The Pastor as Revivalist. In Sang Lee H and Guelzo AC (eds) Edwards in Our Time: Jonathan Edwards and the Shaping of American Religion. Grand Rapids, MI: Cambridge, U.K.

Gerstner JH (1991-1993) The Rational Biblical Theology of Jonathan Edwards, 3 volumes. Orlando, FA: Ligonier.

Kimnach WH (1992) Introduction. In The Works of Jonathan Edwards, Sermons and Discourses, 1720-1723, volume 10. New Haven, CT: Yale University Press.

Lambert F (1999) Inventing the 'Great Awakening'. Princeton, NJ: Princeton University Press.

Marsden GM (2003) Jonathan Edwards, A Life. New Haven \& London: Yale University Press.

Miller P (1953) The New England Mind: From Colony to Province. Belknap: Harvard University.

Nichols SJ (2001) Jonathan Edwards: A Guided Tour of His Life and Thought. Phillipsburg, NJ: P\&R.

Smith JE (1959) Editor's Introduction. In Religious Affections. In Smith JE (ed) The Works of Jonathan Edwards, volume 2. New Haven, CT: Yale University Press.

Stoever WKB (1996) The Godly Will's Discerning. In Stein SJ (ed) Jonathan Edwards's Writings: Text, Context, Interpretation. Bloomington, IN: Indiana University Press.

Story AF Jr (1994) Promoting Revival: Jonathan Edwards and Preparation for Revival. PhD Thesis, Westminster Theological Seminary.

Stout HS (1988) The Puritans and Edwards. In Hatch NO and Stout HS (eds) Jonathan Edwards and the American Experience. New York, NY: Oxford University Press.

Turnbull RG (1958) Jonathan Edwards the Preacher. Grand Rapids, MI: Baker. Walls AF (2003) Missions and Historical Memory: Jonathan Edwards and David Brainerd. In Kling DW and Sweeney DA (eds) Jonathan Edwards at Home and Abroad. Columbia, SC: University of South Carolina Press.

Westra HP (1999) Divinity's Design: Edwards and the History of the Work of Revival. In Lee SH and Guelzo AC (eds) Edwards in Our Time: Jonathan Edwards and the Shaping of American Religion. Grand Rapids, MI: Cambridge.

[This article was published previously is Moga D (2008) The Theology of Revival in Jonathan Edwards. Oradea: Emanuel University Press, pp. 69-95.] 